\title{
Stanisława Kowalskiego poznańska szkoła pedagogiki społecznej*
}

\section{Stanisław Kowalski's Poznań school of social pedagogy}

\begin{abstract}
A B S T R A C T: The text presents an outline of the scientific biography of professor Stanisław Kowalski (1904-1990), the co-founder of the Poznań school of sociology of upbringing and social pedagogy. He was a student of Florian Znaniecki and Stefan Błachowski, and the beginnings of his independent research and didactic activity in 1945 are connected with the University of Łódź, where he cooperated with Józef Chałasiński and Jan Szczepański. After returning to Poznań, he formed a resilient team at the university, intent on diagnosing the broadly understood relationship between education and the environmental conditions of social and cultural life. Kowalski published many monographs and studies, including the widely known Sociologia wychowania (Sociology of Education 1974). Under his scientific direction, a large group of independent research workers dealing with sociology and pedagogy came of age. These people - who already include representatives of three generations of scientists - and their works create a scientific environment known as the Poznań School of Social Pedagogy.
\end{abstract}

KEYW ORDS: Stanisław Kowalski, Adam Mickiewicz University in Poznań, sociology of education, social pedagogy.

STRESZCZEN IE: W tekście przedstawiono zarys biografii naukowej profesora Stanisława Kowalskiego (1904-1990), wspóttwórcy poznańskiej szkoły socjologii wychowania oraz pedagogiki społecznej. Był uczniem

* Tekst wygłoszony na konferencji poświęconej jubileuszowi 40-lecia Katedry Pedagogiki Społecznej Uniwersytetu Śląskiego. Ustroń, 14-15 października 2019 r. 
Floriana Znanieckiego oraz Stefana Błachowskiego, a przypadające na 1945 r. początki jego samodzielnej działalności badawczej i dydaktycznej łączą się z Uniwersytetem Łódzkim, gdzie współpracował m.in. z Józefem Chałasińskim oraz Janem Szczepańskim. Po powrocie do Poznania utworzył w uniwersytecie prężny zespół badawczy, skierowany na diagnozę szeroko rozumianej relacji edukacja-środowiskowe warunki życia społecznokulturalnego. Kowalski opublikował wiele prac monograficznych i studiów, m.in. szeroko znaną Socjologię wychowania (1974). Pod jego kierunkiem naukowym wyrosło liczne grono samodzielnych pracowników naukowych zajmujących się socjologią oraz pedagogiką. Są to już przedstawiciele trzech generacji uczonych, a ich dzieła tworzą środowisko naukowe określane mianem poznańskiej szkoły pedagogiki społecznej.

SŁoWA KLUCZOWE: Stanisław Kowalski, Uniwersytet Adama Mickiewicza w Poznaniu, socjologia wychowania, pedagogika społeczna.

Spiąć czas miniony z teraźniejszością oraz z tym, co prawdopodobnie przyniesie spodziewana przyszłość $\mathrm{w}$ naszym pedagogicznym gronie i środowisku, w uprawianej w nim refleksji teoretycznej i projektach badawczych, to wyzwanie jakiemu może sprostać w zasadzie geniusz intelektualny, lecz także zespół osób, które często określa się mianem dobrze prowadzonej przez mistrza szkoły naukowej. Niewątpliwie istotną rolę odgrywają czasy historyczne w jakich owe szkoły się kształtują i funkcjonują. Dla pedagogów, dla szansy realizacji proponowanych przez nich rozwiązań i identyfikowanych przez nich problemów pedagogicznych nie jest obojętny klimat polityczny, warunki ekonomiczne, stan zinstytucjonalizowania życia społecznego zwłaszcza w sferze edukacyjnej i socjalnej i niewątpliwie przyzwolenie społecznie na realizację owych pedagogicznych ingerencji. Nie jest obojętny w tym względzie stan i obraz zinstytucjonalizowania uprawianej przez nas dyscypliny i poziom profesjonalizacji osób zaangażowanych w jej reprezentację, identyfikujących się $\mathrm{z}$ jej genezą, historią i posłannictwem, dostatecznie kompetentnych do jego rozumienia i zdeterminowanych w osiąganiu stanów uznanych za wartościowe.

$\mathrm{W}$ historii rodzimej pedagogiki społecznej mamy do czynienia $\mathrm{z}$ takimi szkołami, które symbolizuje w miarę wiernie „drzewo” wymyślone, skonstruowane i „zasadzone” w naszej świadomości przez Tadeusza Pilcha z udziałem Tomasza Sosnowskiego. To niewątpliwie istotny zaczyn do dyskusji nad tym, na ile zarysowane w nim konary, zasiedlające je reprezentacje osób, faktycznie służą jeszcze swoją twórczością, swoimi przedsięwzięciami i dokonaniami twórczymi, spinaniu owych trzech wymiarów temporalnych $\mathrm{w}$ jakich mamy nadzieję uprawiać rodzimą pedagogikę społeczną.

Spinają je i dokumentują inicjatywy edytorskie - o charakterze teoretyczno-metodologicznym, podręczniki akademickie pedagogiki społecznej, publikacje o charakterze encyklopedycznym i periodyki, takie jak np. „Pedagogika Społeczna” czy „Chowanna”. Także publikacje autorskie dwojakiego rodzaju: 
ujawniające nowe, obiecujące koncepcje teoretyczne, i takie, które relacjonują wartościowy pod względem poznawczym materiał faktograficzny. $Z$ jednej strony, ujawniają one stany uznane za wymagające interwencji pedagogicznej, $\mathrm{z}$ drugiej zaś ukazują procedury wdrażania projektowanych $\mathrm{w}$ naszej dyscyplinie ingerencji optymalizujących względnie je przezwyciężających, w ich dynamicznej postaci i kontekstach społecznych (instytucjonalnych, środowiskowych i ogólnospołecznych), skłaniając do refleksji nad przedmiotem naszej dyscypliny i potrzebą jego modyfikacji, względnie radykalnej zmiany.

W swoim wystąpieniu pragnę zaprezentować jedną z takich szkół - przez twórców owego „drzewa genealogicznego” określoną mianem szkoły poznańskiej, szkoły Profesora Stanisława Kowalskiego, nadal owocującą także w obszarze interesującej nas orientacji i dyscypliny pedagogicznej.

Stanisław Kowalski - Wielkopolanin z urodzenia, był absolwentem i profesorem Uniwersytetu im. Adama Mickiewicza w Poznaniu. Studia uniwersyteckie - w tej uczelni - ukończył w 1930 r., angażując się zawodowo w Seminarium Nauczycielskim w Rawiczu, Lesznie i Poznaniu, społecznie zaś w Zakładzie Karnym w Rawiczuํ. W tym czasie (lata 30. XX w.), przygotowuje dysertację doktorską poświęconą przestępczości dziecięcej pod kierunkiem Floriana Znanieckiego i składa ją gotową do obrony, wraz z akceptacją promotora, w 1939 r. w Uniwersytecie Poznańskim, oczekując na zapowiedziany powrót swojego mistrza ze Stanów Zjednoczonych. Wybuch drugiej wojny światowej odracza jej obronę aż do 1947 r. Kowalski, pod trwałą już nieobecność promotora, broni ją u prof. Stefana Błachowskiego.

Wcześniej jednak, bo już w 1945 r., podejmuje staż asystencki w Uniwersytecie Łódzkim u prof. Józefa Chałasińskiego. Tu również współpracuje $\mathrm{z}$ doktorantem wypromowanym przez prof. Znanieckiego - prof. Janem Szczepańskim. Interesuje się problematyką wychowawczą rodzin, przygotowuje także monografię poświęconą problematyce osobowości. Po uzyskaniu stopnia kandydata nauk pedagogicznych w roku 1950 przechodzi do Uniwersytetu Poznańskiego. Otrzymuje zadanie kierowania Katedrą Psychologii II, którą prowadzi do początku lat 60 . XX w. W tym czasie opracowuje i publikuje kil-

1 Urke-Nachalnik (1933), Życiorys własny przestępcy, przedmowę napisał dr Stefan Błachowski, opracował i wstęp napisał Stanisław Kowalski, mgr fil., Poznań, Nakład Towarzystwa Opieki nad Więźniem. Patronat - Oddział Rawicz. „Życiorys...” ten został wznowiony w 2018 r. przez wydawnictwo Replika. 
ka monografii poświęconych rozwojowi mowy i myślenia dziecka (Kowalski 1956, 1959, 1962).

W początkach lat sześćdziesiątych Senat UAM zleca Profesorowi Kowalskiemu kolejne zadanie, jakim jest rewitalizacja Katedry Socjologii, a w zasadzie wznowienie jej w strukturze nauk uniwersyteckich po okresie politycznej hibernacji akademickiej nauki socjologicznej. Kontynuuje w tym czasie Profesor prowadzenie seminarium doktorskiego, w którym doktorat broni mgr Władysław Markiewicz - później profesor i wiceprzewodniczący PAN.

Po trzech latach, w chwili podjęcia przez prof. Kwiatka, ówczesnego kierownika Katedry Pedagogiki UAM, funkcji Ministra Oświaty - przejmuje Kowalski z kolei kierownictwo tej Katedry na kolejne sześć lat, prowadząc badania nad obecnością i funkcjonowaniem systemu szkolnego w typowych środowiskach lokalnych, skutkujące opublikowaniem monografii poświęconej więziom szkoły z jej środowiskiem lokalnym (Kowalski 1969). Badania te, i towarzyszące im studia nad obecnością i funkcjonowaniem systemu szkolnego w środowiskach lokalnych, sprzyjają nawiązaniu ścisłej współpracy z zakładami i katedrami pedagogiki społecznej w kraju.

Profesor współpracuje m.in. w tym czasie z prof. Ryszardem Wroczyńskim (głównie w zespole PAN-owskim, lecz i we wzajemnym udziale w przewodach doktorskich i habilitacyjnych), z prof. Aleksandrem Kamińskim i później z prof. Ireną Lepalczyk, prof. Edmundem Trempałą, angażując się etatowo $\mathrm{z}$ nowo tworzącymi się ośrodkami akademickimi w Szczecinie, Gdańsku (z prof. Romaną Miller, Bolesławem Maroszkiem ), w Zielonej Górze (z Marią Jakowicką, Edwardem Hajdukiem), kontynuując współpracę z pedagogami z Torunia, Wrocławia i Warszawy.

W 1969 r., po przejęciu kierownictwa Katedry Pedagogiki UAM przez prof. Heliodora Muszyńskiego i jej przemianowaniu na Instytut Pedagogiki, Profesor Stanisław Kowalski w nowo powstałej strukturze podejmuje i pełni funkcję kierownika Zakładu Pedagogiki Społecznej, przekształconego z wcześniej funkcjonującego pod Jego kierownictwem Zakładu Socjologii Wychowania. Rozwija w tym czasie swoje zainteresowania poznawcze socjologiczną problematyką selekcji szkolnych (Kowalski 1972) i wychowawczym funkcjonowaniem, względnie wychowawczą dysfunkcją, społeczności lokalnych.

W tym Zakładzie w 1970 r. piszący te słowa zostaje zatrudniony na etacie asystenckim, i przygotowuje dysertację doktorską poświęconą problematyce wychowawczej funkcji szkoły wyższej, obronioną w 1977 r. Kierowany przez Profesora Zakład Pedagogiki Społecznej, a w rzeczywistości socjologii wychowania, a dzisiaj powiedzielibyśmy socjopedagogiki, skupiał wówczas liczne grono asystentów, adiunktów i słuchaczy studium doktorskiego, wśród 
których wówczas byli: Jan Włodarek, Władysław Dykcik, Jan Kupczyk, Stanisław Wawryniuk, Andrzej Pfeiffer, Dzierżymir Jankowski. Do tego zespołu, rok później dołączyli moi koledzy z lat studiów: Wiesław Ambrozik i Tadeusz Frąckowiak - słuchacze Studium doktorskiego funkcjonującego przy Instytucie Pedagogiki UAM. Wszyscy w wyznaczonym ustawowo czasie obronili u Profesora prace doktorskie i następnie (poza dr. Andrzejem Pfeifferem) również habilitacyjne. Doktorzy Profesora Stanisława: Władysław Dykcik, Dzierżymir Jankowski, Tadeusz Frąckowiak, Jerzy Modrzewski i Wiesław Ambrozik uzyskali także tytuł naukowy.

Profesor Stanisław, po ukończeniu siedemdziesiątego roku życia (1974), przeszedł na zasłużoną emeryturę, nie rezygnując z kontynuacji opieki naukowej „swoich chłopców”, jak nas nazywał, publikując dzieło życia - podręcznik socjologii wychowania, zachowując dotychczasową dynamikę twórczą i zaangażowanie w sprawy naukowe (Kowalski 1974a).

\section{II}

W okresie kierowania Zakładem Profesor podejmuje i pełni funkcję kierownika ogólnopolskiego, PAN-owskiego zespołu badawczego diagnozującego kondycję wychowawczą wiejskich i miejskich środowisk lokalnych. W zespole tym, funkcjonującym przez wiele kolejnych lat, poza pracownikami poznańskiego Zakładu Pedagogiki Społecznej spotykają się przedstawiciele w zasadzie wszystkich środowisk akademickich, w których istnieją zakłady pedagogiki społecznej bądź socjologii wychowania (później przemianowane na zakłady socjologii edukacji).

Profesor inicjuje i rozwija teoretyczne podstawy prowadzonych w nim badań terenowych, tworząc oryginalną koncepcję metodologiczną tak zwanego systemowego podejścia do wychowawczego funkcjonowania społeczności lokalnych i zbiorowości terytorialnych (Kowalski 1974b, 1984b, 1984c, 1988; Kowalski, Wawryniuk (red.) 1984a). W połowie lat 70., po przejściu Profesora na emeryturę, badania te są kontynuowane $w$ ramach tak zwanego problemu resortowego 11.4 (lokalne społeczności wychowujące) pod kierunkiem Zbigniewa Kwiecińskiego - zespół poznański bierze w nich czynny udział. Profesor Kwieciński przejmuje w roku 1976 kierownictwo Zakładu Pedagogiki Społecznej UAM.

$\mathrm{Z}$ inspiracji Profesora Stanisława powstaje w tym czasie wiele monografii uwzględniających i stosujących to podejście (jeszcze w czasie kierowania zespołem PAN, jak i w okresie późniejszym). Tytułem przykładu wskażę tu tylko niektóre opracowania autorstwa: Włodzimierza Wincławskiego (1976), 
Marii Jakowickiej (1979), czy Zbigniewa Kwiecińskiego (1972), inspirowane Kowalskiego koncepcją systemowej analizy wychowawczego funkcjonowania środowisk lokalnych, uwzględniające także inspiracje zawarte w Znanieckiego koncepcji społeczeństwa wychowującego (Znaniecki 1974).

Swoje prace poświęcone problematyce wychowawczego funkcjonowania środowisk lokalnych konsultują z Profesorem: Edmund Trempała, Jerzy Materne, Stanisław Kawula (1973) i inni, a Mirosław Szymański, Zbigniew Kwieciński (także inni) kontynuują, m.in. z inspiracji i w konsultacji z Profesorem Stanisławem, swoje zainteresowania procesami selekcyjnymi i niesprawiedliwym społecznie dostępem do edukacji młodzieży wywodzącej się z niższych warstw społecznych i zmarginalizowanych kulturowo i ekonomicznie środowisk (np. Kwieciński 1975), które na przełomie lat 70. i 80. zaprzątać będą uwagę i zaangażowanie poznawcze Tadeusza Frąckowiaka (1986), stanowiąc o jego dorobku habilitacyjnym, a później np. Barbary Smolińskiej-Theiss (2015) i kilku innych pedagogów oraz socjologów edukacji. Autorskie inicjatywy poznawcze i badawcze konsultują wówczas z Profesorem osoby reprezentujące szczecińskie, gdańskie, bydgoskie, toruńskie, wrocławskie i zielonogórskie środowiska akademickie. Udokumentowaniem efektów tej współpracy są kolejne redagowane przez Profesora tomy „Studiów Pedagogicznych” (1974b, 1984a).

To w tych latach spotykamy się regularnie w zespole seminaryjnym Profesora, przygotowując swoje prace doktorskie (Włodarek 1977; Modrzewski 1977; Jankowski 1977; Wawryniuk 1976; Kupczyk 1978; Dykcik 1979; Pfeiffer 1979; Frąckowiak 1980; Ambrozik 1983). W każdej z nich pozostały ślady i twórcze autorskie dopełnienia inspiracji profesorskiej teorii systemowego podejścia do oglądu i projekcji ich przedmiotów, takich jak: szkoły rozmaitych typów i szczebli kształcenia, domy kultury, organizacje dziecięce i młodzieżowe, rodziny, grupy rówieśnicze, środki masowego przekazu oraz całe środowiska lokalne: wiejskie i miejskie.

\section{III}

Z Profesorem Stanisławem spotykamy się także w czasie, gdy pozostaje On w okresie zaawansowanej emerytury, dzieląc się nowinkami i dorobkiem naukowym, oczekując rady i zachęty do podejmowania kolejnych wysiłków awansowych, komentując także aktualne wydarzenia polityczne i spodziewane z niepokojem, ale i nadzieją, ich konsekwencje dla kraju, dla środowisk akademickich, dla każdego $\mathrm{z}$ nas - mniej lub bardziej zaangażowanego i zidentyfikowanego $\mathrm{z}$ dynamiką i kierunkiem przemian ustrojowych. 
W 1984 r. jako uczniowie Profesora organizujemy ogólnopolską konferencję poświęconą Jego osiemdziesiątym urodzinom. Profesor jest jeszcze w świetnej formie intelektualnej, patronuje naszym wysiłkom zmierzającym ku habilitacjom. Na tej jubileuszowej konferencji Profesor wygłasza referat podsumowujący dokonania już niekierowanego formalnie przez siebie zespołu, ze wskazaniem dalszych kierunków badań adresowanych do każdego z nas - po części już kierujących lub zaangażowanych $\mathrm{w}$ prace swoich zespołów badawczych. Konferencję tę upamiętniła publikacja zredagowana przez prof. H. Muszyńskiego, a opublikowana z pięcioletnim opóźnieniem (1989).

Składa się na nią zbiór artykułów przygotowanych przez osoby współpracujące z Profesorem, lecz także jego doktorów i przyjaciól, pragnący uświetnić Jego 80-lecie swoim uczestnictwem w konferencji, która w 1984 r. zgromadziła przeszło 300 reprezentantów większości polskich środowisk akademickich. Na tym spotkaniu Prof. Bogdan Suchodolski wygłosił prawie dwugodzinny wykład (wysłuchany z niezwykłą uwagą przez uczestników konferencji) a poświęcony perspektywie nauk pedagogicznych i kondycji pedagogicznej współczesnych społeczeństw cywilizacji euroamerykańskiej.

Teksty pomieszczone w tym tomie nawiązywały do życiowego dorobku naukowego Profesora Stanisława. Środowisko pedagogiki społecznej Uniwersytetu Łódzkiego reprezentowała wówczas prof. Irena Lepalczyk wygłaszając tekst poświęcony ośrodkom pedagogiki społecznej uprawianej w Polsce (Lepalczyk 1989) oraz prof. Ewa Marynowicz-Hetka przedstawiając referat ujawniający zagrożenia rozwojowe dzieci uspołeczniających się w rodzinach dysfunkcjonalnych (Marynowicz-Hetka 1989). Śląskie środowisko pedagogów społecznych reprezentował na spotkaniu doc. Henryk Gąsior z tekstem poświęconym współdziałaniu pedagogiki społecznej z socjologią wychowania, inicjując kontynuowany następnie przez 40 lat okres faktycznej, niezwykle dynamicznej i bogatej w doświadczenia i dorobek naukowy współpracy pomiędzy Katedrą Pedagogiki Społecznej UŚ a zakładami pedagogicznymi wpierw Instytutu Pedagogiki UAM, i następnie Wydziału Studiów Edukacyjnych tej uczelni.

Szczególne zasługi w tym względzie przynależą prof. dr hab. Andrzejowi Radziewiczowi-Winnickiemu - z niezwyczajną życzliwością patronującemu akademickiej obecności „chłopaków od Kowalskiego”, inicjatora wielu publikacji podnoszących zagadnienie wzajemnych związków socjologii wychowania i pedagogiki społecznej (np. A. Radziewicz-Winnicki (red.) 1986), a także publikacji zawierającej biogram naukowy Profesora Stanisława (Radziewicz-Winnicki (red.) 1993). Niezwykle życzliwie i wielce owocne zaangażowanie we współpracę z poznańskimi pedagogami społecznymi w całym okresie funkcjonowania Zakładu Pedagogiki społecznej UAM miała prof. dr hab. Ewa Syrek, 
a także prof. dr hab. Anna Nowak i dr hab. Ewa Jarosz. Z kolei ze strony poznańskiej znaczne zasługi w umacnianiu i rozwijaniu owej współpracy należą się głównie uczniom profesora Stanisława, kojarzonym z pedagogiką społeczną, specjalną, resocjalizacyjną, socjologią wychowania i także dydaktyką.

W roku 1994 - a więc w cztery lata po odejściu w zaświaty Profesora Stanisława - jego spadkobiercy naukowi: uczniowie i przyjaciele, organizują kolejną konferencję naukową poświęconą Jego osobie i dorobkowi naukowemu. Poprzedza ją publikacja zredagowana przez W. Ambrozika, T. Frąckowiaka i S. Wawryniuka pod tytułem: Pamięć i obecność społeczna (1994). Uczestniczą $\mathrm{w}$ konferencji reprezentanci prawie wszystkich środowisk akademickich w Polsce, w których uprawia się pedagogikę społeczną i socjologię wychowania. Jest na niej obecny także T. Pilch - ówczesny wiceminister oświaty, wspiera nas radą i pochwałą. Konferencja staje się okazją do wspominania Profesora, ale i zaprezentowania dorobku „chłopaków od Kowalskiego”, wskazania dalszych kierunków rozwoju problematyki uprawianej w poznańskim zespole pedagogów społecznych i w znacznej mierze w innych zaprzyjaźnionych z poznaniakami zespołach (m.in. pracowników Katedry Pedagogiki Społecznej UŚ).

Już dwa lata później pod red. Tadeusza Frąckowiaka ukazuje się tom studiów: Koncepcje pedagogiki społecznej (1996), z tekstami m.in.: T. Pilcha, Z. Kwiecińskiego, A. Radziewicza-Winnickiego, S. Kawuli, Z. Wołka, B. Chmielowskiego i wielu innych, także poznaniaków. Jest to dokument świetnie rozwijającej się międzyśrodowiskowej współpracy polskich pedagogów społecznych, których teksty w takiej czy innej formie nawiązywały do koncepcji teoretycznych Kowalskiego, zwłaszcza jego koncepcji systemowego ujmowania wychowawczego funkcjonowania i dysfunkcyjności wychowawczej społeczności lokalnych wsi i miejskich zbiorowości terytorialnych².

Tom ten, podobnie jak nieco wcześniej opublikowana monografia habilitacyjna Jana Włodarka, dedykowana Profesorowi Stanisławowi a poświęcona socjologii wychowania (1992), kontynuował serię wcześniejszych i otwierał serię kolejnych wydawnictw - monografii autorskich i współautorskich przygotowanych i opublikowanych przez doktorów Profesora - prowadzących już własne zespoły asystentów i doktorów. W 1991 roku publikuje swoją rozprawę habilitacyjną dr Wiesław Ambrozik (1991), a nieco wcześniej, bo w 1989 roku monografię habilitacyjną poświęconą socjalizacyjnemu funkcjonowaniu środowiska akademickiego publikuje autor niniejszego tekstu. W tym samym roku ukazuje się monografia habilitacyjna dr. Dzierżymira Jankowskiego (1989), a rok później Stanisława Wawryniuka (1990).

2 Przypomniał tę koncepcję w ostatnim czasie Profesor Wiesław Ambrozik (2018). 
W roku 1995 wraz z profesorem Tadeuszem Frąckowiakiem redagujemy tom poświęcony procesowi socjalizacji wartości (1995). To kolejna okazja do zaprezentowania sukcesywnie pomnażanego dorobku zespołu doktorów Profesora Stanisława Kowalskiego, ale także już i naszych magistrów i zaprzyjaźnionych z nami osób - reprezentujących liczne pozapoznańskie środowiska akademickie. Aktywność publikacyjną w kolejnych latach ujawniają członkowie zespołów kierowanych przez doktorów Profesora Stanisława.

Zespoły kierowane przez prof. Tadeusza Frąckowiaka, a po Jego odejściu przez prof. Katarzynę Segiet, prof. Wiesława Ambrozika i piszącego te słowa, wraz ze współpracującymi z nami przedstawicielami innych zakładów i środowisk akademickich, publikują wiele monografii, które w różnym zakresie uwzględniają teoretyczne propozycje Profesora Stanisława. Profesor Jan Włodarek, wieloletni dyrektor Instytutu Socjologii UAM, kontynuuje w swoim zespole (we współpracy z prof. Wiesławem Ambrozikiem i autorem tego opracowania) badania nad przebiegiem i efektami procesu socjalizacji młodzieży szkół podstawowych i gimnazjalnych (w kooperacji z Uniwersytetem w Bielefeld i prof. Klausem Hurrelmannem). To w tym czasie redagujemy tom poświęcony antologii tekstów z socjologii wychowania (1998). Prof. Władysław Dykcik, kierując Zakładem Pedagogiki Specjalnej łączy w badaniach kierowanego przez siebie zespołu (i własnych) psychologiczne i socjologiczne aspekty obecności społecznej osób niepełnosprawnych.

Do Kowalskiego koncepcji organizacji i funkcjonowania środowiskowego systemu profilaktyki i resocjalizacji nawiązuje w swojej twórczości prof. Wiesław Ambrozik, kierując Zakładem Pedagogiki Resocjalizacyjnej, orientując ku tej koncepcji przygotowywane pod Jego kierunkiem doktoraty a także liczne własne publikacje i autorski podręcznik pedagogiki resocjalizacyjnej, w którym rozwija i ugruntowuje Kowalskiego koncepcję środowiskowej profilaktyki prewencyjnej (Ambrozik 2016; Dzięcioł 2001; Pawełek 2002; Muskała 2004; Barczykowska 2006; Boćko 2009). Podobnie prof. Dzierżymir Jankowski wraca w swoich publikacjach do problematyki środowiskowej obecności szkoły. To tylko kilka $\mathrm{z}$ wielu przykładów żywotności i płodności refleksji teoretycznej i metodologicznej Profesora Stanisława skutkujące także w drugim niejako pokoleniu - doktorów Jego doktorów, np. niektóre prace doktorskie przygotowane pod kierunkiem piszącego ten tekst (Łukomska 2007; Zychowicz 2014; Kościelniak 2016; Grześko-Nyczko 2016; Dworniczek 2018).

Swoistą pośmiertną żywotność Profesora, Jego ideacyjną obecność społeczną, utrwalają kolejne organizowane przez nas - jego doktorów, a pozostało nas już niewielu - konferencje poświęcone Profesorowi - pamięci o Nim i jego twórczości. W roku 2004 w stulecie urodzin Profesora organizujemy ka- 
meralne seminarium $\mathrm{z}$ udziałem naszych zespołów zakładowych, ale i reprezentantów innych środowisk, którzy z mniejszym czy większym sentymentem identyfikują się z Profesorem i Jego uczniami. Jednodniowe seminarium zwieńczył wieczór wspomnień i anegdot Mu poświęconych i kolorytowi kreowanych przez Niego sytuacji, w których uczestniczyliśmy i które zapadły nam głęboko $\mathrm{w}$ pamięci. Materiały $\mathrm{z}$ tego spotkania nie zostały opublikowane, ale nie są stracone. Nacisk bieżących spraw był wówczas tak silny, że odłożyliśmy to zadanie do zrealizowania w czasie późniejszym. Czekały one na nasze redaktorskie zmiłowanie do 2019 roku.

Nieco wcześniej, bo pod koniec 2018 roku, z inicjatywy prof. Wiesława Ambrozika i z moim udziałem pojawiła się koncepcja upamiętnienia osoby Profesora Stanisława tablicą pamiątkową pomieszczoną w hallu jednego $\mathrm{z}$ reprezentacyjnych gmachów dydaktycznych campusu UAM na Szamarzewie. Jej odsłonięcie - z udziałem władz rektorskich i wydziałowych, a także członków rodziny Profesora, jego doktorów i byłych studentów, a obecnie profesorów uniwersyteckich miało miejsce w dniu 14 grudnia 2018 r. i dopełnione zostało seminarium gromadzącym liczne grono osób spokrewnionych z Profesorem, Jego uczniów i słuchaczy jego wykładów, a także młodzieży - jeszcze studiującej, i już wchodzącej na ścieżkę awansu naukowego.

Przygotowujemy kolejną książkę poświęconą Profesorowi, z Jego autorskim znacznym udziałem, bogato ilustrowaną, $\mathrm{z}$ nadzieją, a nawet ugruntowanym przeświadczeniem, że pamięć o Profesorze i Jego dorobku naukowym skutecznie przezwycięży destrukcyjny upływ czasu, nie tracąc, a nawet zyskując, na swojej atrakcyjności i poznawczej inspiracji w konfrontacji z nowym, już doświadczanym i jeszcze nieznanym, już zapowiadanym i interpretowanym przez zespoły drugiego pokolenia poznańskiej pedagogiki społecznej, profesorów, profesorów Profesora Stanisława.

\section{Bibliografia wybranych publikacji Stanisława Kowalskiego jego uczniów i ich uczniów}

Ambrozik W. (1983), Sytuacja społeczna dziecka rodziny alkoholicznej, Poznań: WN UAM.

Ambrozik W. (1991), Wychowawcze funkcjonowanie średniego miasta uprzemysłowionego. Analiza systemowa ze szczególnym uwzględnieniem funkcji samoregulujących, Poznań: WN UAM. Ambrozik W. (1997), Dewiacje wychowawcze w środowisku wiejskim, Poznań: Eruditus.

Ambrozik W. (2010), Społeczność lokalna płaszczyzna funkcjonowania systemu profilaktyczno-resocjalizacyjnego, „Resocjalizacja Polska”, nr 1.

Ambrozik W. (2016), Pedagogika resocjalizacyjna. W stronę uspołecznienia systemu oddziaływań, Kraków: Oficyna Wydawnicza „Impuls”.

Ambrozik W. (2018), O podejściu systemowym w badaniu środowisk wychowawczych raz jeszcze, [in:] Modrzewski J., Matysiak-Błaszczyk A., Włodarczyk E. (red.), Środowiska uczest- 
nictwa społecznego jednostek, kategorii i grup (doświadczenia socjalizacyjne i biograficzne), Poznań: WN UAM.

Ambrozik W., Modrzewski J. (red.) (1988), Problematyka wychowania w twórczości polskich socjologów, Koszalin: WU BWSzH.

Ambrozik W., Frąckowiak T., Wawryniuk S. (red.) (1994), Pamięć i obecność społeczna, Poznań: Prodruk.

Barczykowska A. (2006), Kapitał społeczny a zjawiska patologii społecznej wielkomiejskich społeczności lokalnych, mps pracy doktorskiej napisanej pod kierunkiem prof. W. Ambrozika.

Barczykowska A. (2011), Kapitał społeczny a zjawiska patologii społecznej w wielkomiejskich spoŁecznościach lokalnych, Kraków: Oficyna Wydawnicza „Impuls”.

Barczykowska A. (2019), Systemy wychowawcze gentryfikujacych społeczności lokalnych. Rozpad - stagnacja - rozwój, Poznań: WN UAM.

Barczykowska A., Muskała M. (red.) (2017), Horyzonty pedagogiki resocjalizacyjnej, Poznań: WN UAM.

Boćko P. (2009), Wieś popegeerowska jako zdezorganizowane środowisko wychowawcze, Poznań, mps pracy doktorskiej napisanej pod kierunkiem W. Ambrozika.

Dąbrowska-Bąk, Pawełek K. (2013), Dysfunkcjonalność lokalnego społeczeństwa wychowującego, Poznań: WN UAM.

Dworniczek K. (2018), Bieda w doświadczeniu uczniów szkół leszczyńskich i jej socjalizacyjne konsekwencje, Poznań, mps pracy doktorskiej napisanej pod kierunkiem J. Modrzewskiego.

Dykcik W. (1979), Wspótpraca szkoły specjalnej ze środowiskiem, Poznań: WN UAM.

Dzięcioł B. (2001), Funkcjonowanie kontroli społecznej wobec dziecka w kulturowo zaniedbanym rejonie wielkiego miasta, mps pracy doktorskiej napisanej pod kierunkiem prof. W. Ambrozika.

Dzięcioł B. (2002), Poza kontrolą. Funkcjonowanie kontroli społecznej wobec dziecka w wielkim mieście, Poznań: OW Garmond.

Frąckowiak T. (1980), Uspołecznianie młodzieży poprzez studia wyższe, Poznań: WN UAM.

Frąckowiak T. (1986), Selekcje szkolne $w$ typowych środowiskach wychowawczych współczesnej Polski, Poznań: WN UAM.

Frąckowiak T., Mosiek P., Radziewicz-Winnicki A. (red.) (2005), Społeczne procesy modernizacyjne w środowisku lokalnym średniego miasta (doświadczenia i propozycje), Rawicz-Leszno: Wydawnictwo Urzędu Miejskiego Gminy Rawicz.

Frąckowiak T., Modrzewski J. (red. ) (1995), Socjalizacja a wartości (aktualne konteksty), Poznań: Eruditus.

Frąckowiak T. (red.) (1996), Koncepcje pedagogiki społecznej, Poznań: Eruditus s.c.

Frąckowiak T. (red.) (2001), Arytmia egzystencji społecznej a wychowanie, Warszawa: Fundacja Innowacja i WSzSE.

Frąckowiak T. (red.) (2005), Dziecko i edukacyjne oferty małych ojczyzn, Poznań. WN PTPS.

Grześko-Nyczka M. (2016), Społeczny problem dezorganizacji i dysfunkcjonalności rodziny w środowisku średniego miasta, Poznań, mps pracy doktorskiej napisanej pod kierunkiem J. Modrzewskiego.

Jakowicka M. (1979), Uwarunkowania funkcjonowania szkót środowiskowych $w$ średnim mieście, Zielona Góra: WN WSP.

Jankowiak B., Matysiak-Błaszczyk A. (red.) (2017), Młodzież między ochrona a ryzykiem, Poznań: WN UAM. 
Jankowski D. (1977), Dom kultury. Studium socjologiczno-pedagogiczne, Warszawa: COMiUK.

Jankowski D. (1989), Wychowawcze perspektywy działalności kulturalno-oświatowej, Poznań: WN UAM.

Jankowski D. (1993), Wychowawcze perspektywy działalności kulturalno-oświatowej, Kalisz: KP-A UAM i WOM.

Jankowski D. (red.) (2003), Szkoła w społeczności lokalnej, Kalisz: WPA UAM.

Kawula S. (1973), Rodzina wiejska a wychowanie, Toruń: WN UMK.

Kowalski S. (1956), Przyczynek do zagadnienia faz rozwoju myślenia i języka dziecka [wraz z komunikatami wspótpracowników], Poznań: PWN.

Kowalski S. (red.) (1959), Rozwój mowy pisanej u dzieci wczesnych klas szkoły podstawowej, Poznań: PWN.

Kowalski, S. (1962), Rozwój mowy i myślenia dziecka, Warszawa: PWN.

Kowalski S. (1969), Szkoła w środowisku, Warszawa: PZWS.

Kowalski S. (1974a), Socjologia wychowania $w$ zarysie, Warszawa: PWN.

Kowalski S. (1984a), Podejście systemowe $w$ badaniu środowisk wychowawczych [w:], S. Kowalski, S. Wawryniuk (red.), Doskonalenie systemu wychowawczego w środowisku, Wrocław: Ossolineum.

Kowalski S. (1984b), Środowisko lokalne w wychowawczym funkcjonowaniu społeczeństwa, „Rocznik Pedagogiczny", t. 9.

Kowalski S. (1984c), Znaczenie teorii systemów społecznych Floriana Znanieckiego w interdyscyplinarnych badaniach nad wychowaniem, „Edukacja”, nr 2.

Kowalski S. (1988), Wychowawcze funkcjonowanie społeczeństwa, „Kwartalnik Pedagogiczny”, nr 1 .

Kowalski S. (red.) (1972), Selekcyjne funkcje wychowania, Wrocław: Ossolineum.

Kowalski S. (red.) (1974b), Funkcjonowanie systemu wychowawczego w środowisku, Wrocław: Ossolineum.

Kościelniak M. (2016), Leszczyńskie rodziny zastępcze i ich podopieczni. Socjopedagogiczne studium zinstytucjonalizowanej formy opieki kompensacyjnej, Poznań, mps pracy doktorskiej napisanej pod kierunkiem J. Modrzewskiego.

Kubiak-Krzywicka W. (2010), Interakcyjno-kontekstualny model zaburzonej socjalizacji, Poznań-Kalisz. UAM WPA.

Kupczyk J. (1978), Uwarunkowania aspiracji życiowych młodzieży w starszym wieku szkolnym, Poznań: WN UAM.

Kwieciński Z. (1972), Funkcjonowanie szkoły w środowisku wiejskim, Warszawa: PWN.

Kwieciński Z. (1975), Selekcja społeczna w szkolnictwie ponadpodstawowym ,Warszawa: IRWIR PAN. Łukomska M. (2007), Problem prostytucji w środowisku lokalnym. Studium socjopedagogiczne na przykładzie Kołobrzegu, Poznań, mps pracy doktorskiej napisanej pod kierunkiem J. Modrzewskiego.

Matysiak-Błaszczyk A. (2010), Sytuacja życiowa kobiet pozbawionych wolności, Kraków: Oficyna Wydawnicza „Impuls”.

Matysiak-Błaszczyk A., Modrzewski J., Sipińska D. (red.) (2011), Socjalizacja w kategoriach wieku społecznego. Standaryzacja socjalizacji inkluzywnej. Dorosłość i starość, Leszno: PWSZ.

Matysiak-Błaszczyk, Modrzewski J. (red.) (2012), Socjalizacja dysocjacyjna $w$ doświadczeniu indywidualnym i społecznym. Inspiracje teoretyczne i próby pedagogicznych ingerencji, Poznań-Kalisz: UAM WPA.

Matysiak-Błaszczyk A., Jankowiak B. (red.) (2016), Kontrowersje wokót socjalizacji dziewcząt $i$ kobiet, Poznań: WN UAM. 
Matysiak-Błaszczyk A., Włodarczyk E. (red.) (2016), Pedagogika w społeczeństwie - społeczeństwo $w$ pedagogice, Poznań: WN UAM.

Modrzewski J. (1977), Funkcja wychowawcza szkoły wyższej w opinii młodzieży studiującej, Poznań, mps pracy doktorskiej napisanej pod kierunkiem S. Kowalskiego.

Modrzewski J. (1988), Środowisko społeczne młodzieży studiującej, Poznań: WN UAM.

Modrzewski J. (2004, 2007), Socjalizacja i uczestnictwo społeczne, Poznań: WN UAM.

Modrzewski J. (2011), Studia i szkice socjopedagogiczne, Poznań-Kalisz: UAM WPA.

Modrzewski J. (2016), Socjopedagogika. Studia - szkice - refleksje -wspomnienia, Poznań: WN UAM.

Modrzewski J. (red.) (2001), Poznawanie i rozwiązywanie społecznego problemu bezrobocia, Warszawa: Fundacja Rozwoju Polityki Społecznej.

Modrzewski J., Śmiałek J.M., Wojnowski K. (red.) (2008), Relacje podmiotów w lokalnej przestrzeni edukacyjnej (inspiracje...), Kalisz: UAM WPA.

Modrzewski J., Matysiak-Błaszczyk A., Włodarczyk E. (red.) (2018), Środowiska społecznego uczestnictwa jednostek, kategorii i grup. Poznań, WN UAM.

Muskała M. (2004), Więzi osadzonych ze środowiskiem, Poznań: WN UAM.

Muszyński H. (1989) (red.), Socjalizacja - osobowość - wychowanie, Poznań: WN UAM.

Nawrocki Z., Pawlak F., Wojnowski K. (red.) (2011), Środowiskowa podmiotowość społeczności lokalnej w unijnej przestrzeni gospodarczej i społeczno-kulturowej, Leszno: PWSZ.

Pawełek K. (2002), Społeczność lokalna wielkiego miasta wobec zachowań dewiacyjnych dzieci i młodzieży, mps pracy doktorskiej napisanej pod kierunkiem W. Ambrozika.

Pfeiffer A. (1979), Socjalizacja młodzieży akademickiej w wielkim mieście, Poznań, mps pracy doktorskiej napisanej pod kierunkiem S. Kowalskiego.

Pilch T. (2019), Drzewo poznania. Wokół narodzin i rozwoju poznańskiej pedagogiki społecznej, [w:] K. Segiet, K. Słupska, A. Tokaj, Etapy życiowe człowieka w kontekście pedagogiki społecznej, Poznań: WN UAM.

Radziewicz-Winnicki A. (red.) (1986), Pedagogika a socjologia wychowania, Katowice: UŚ.

Radziewicz-Winnicki A. (red.) (1993), Wspótcześni socjologowie o wychowaniu (zarys wybranych koncepcji), Katowice: UŚ.

Segiet K. (2000), Dziecko w wielkim mieście, Poznań: WN UAM.

Segiet K. (red.) (2015), Młodzież $w$ dobie przemian społeczno-kulturowych, Poznań: WN UAM.

Segiet K., Słupska K. (red.) (2017), Ksią̇ka w życiu człowieka - w poszukiwaniu (u) traconej wartości, Poznań. WN UAM.

Segiet K., Słupska K., Tokaj A. (red.) (2017), Animacja w środowisku. O potrzebie kreowania działań lokalnych (teoria a praktyka społeczna), Poznań: WN UAM.

Sipińska D., Modrzewski J., Matysiak-Błaszczyk A. (2010), Socjalizacja w kategoriach wieku społecznego. Standaryzacja socjalizacji inkluzyjnej. Dzieciństwo i młodość. Przewodnik i teksty do ćwiczeń $z$ socjologii wychowania, Leszno: WN PWSZ.

Smolińska-Theiss B. (2015) Z tradycji badań nad nierównościami edukacyjnymi - od społecznych przyczyn powodzeń i niepowodzeń szkolnych do współczesnych badań nad zróżnicowaniami w oświacie, [w:], Gromkowska-Melosik A., Szymański M.J. (red.), Edukacja i nierówność. Trajektorie sukcesu i marginalizacji, Poznań: WN UAM.

Wawryniuk S. (1976), Kształtowanie się systemu wychowawczego w wielkomiejskim osiedlu mieszkaniowym, Poznanń, mps pracy doktorskiej napisanej pod kierunkiem S. Kowalskiego.

Wawryniuk S. (1990), Sity społeczne wychowania w osiedlach mieszkaniowych. Poznań: WN UAM. 
Wincławski W. (1976), Typowe środowiska wychowawcze współczesnej Polski, Warszawa: PWN. Włodarek J. (1977), System wychowawczy zakładu poprawczego. Socjologiczne studium instytucji resocjalizacyjnej, Warszawa: Wydawnictwo Prawnicze.

Włodarek J. (1992), Socjologia wychowania w Polsce, Poznań: WN UAM.

Znaniecki F. (1974), Socjologia wychowania, t. 1 i 2, Warszawa: PWN.

Zychowicz I. (2014), Studenci Koszalina - edukacja i socjalizacja, Koszalin: WN Politechniki Koszalińskiej. 